Jusmal llmial

PFUR AT DE

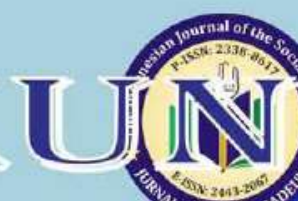

Vol. 5, No. 3, September 2017

$\int_{\substack{\text { Indrjesident } \\ \text { si in }}} 1$

sCAD Intependent Acreditatiou by 100 since 2014 $\bigodot$ Copernicus Publications

\section{JIP}

The Indonesian Journal of the Social Sciences www.journal.scadindependent.ors D01 Prefix Number; 10,26811
Csinta

INDEX COPERNICUS 


\title{
THE EFFECTIVENESS OF ENGLISH TEACHING MODULE AT MIDDLE SCHOOLS IN WEST ACEH
}

\author{
Erizar1 \& Mohd Nazri Latiff Azmi ${ }^{2}$ \\ ${ }^{1}$ Sekolah Tinggi Agama Islam Negeri Teungku Dirundeng Meulaboh, Indonesia \\ ${ }^{2}$ Universiti Sultan Zainal Abidin (UniSZA), Malaysia \\ ${ }^{1}$ ContributorEmail:eri_zar@yahoo.com
}

Received: May 24, 2017

Accepted: Aug 23, 2017

Published: Sep 28, 2017

Article Url: http://journal.scadindependent.org/index.php/jipeuradeun/article/view/150

\begin{abstract}
The purpose of this study is to explore the effectiveness of English Teaching Module at middle schools in West Aceh. The students of middle school studying in Government public school were the population of study. The control group, as well as the experimental group, was of equal size, each has 30 students of 8 th class. The significance of the difference between the scores of groups at 0.05 levels was tested by applying t-test. The result of the study showed the difference between the mean scores of the experimental and control group was found to be highly significant. The $p$-value was found $0.000(P<0.05)$. The study also proved that the material designed, which was useful for slow as well as of bright students, enabled the students to comprehend difficult concepts, and kept them on the track.
\end{abstract}

Keywords: Effectiveness, English, Teaching, Module, West Aceh 


\section{A. Introduction}

Today, English has become the lingua franca of the world, which replaces French in the field of diplomacy, German in the field of science and technology, and Latin in the field of literature and art. It has become an official or co-official language of 45 countries of the world (Minkova \& Stockwell, 2001). However, in some developing countries, such as Indonesia, English is taught as a compulsory subject; yet, the performance of students is very poor. The teacher community is unaware of current research in the field of English language teaching. They follow out-dated methods, which result in boredom and lack of interest in the classroom; this is also related to the poor competency of the teachers in academic and professional areas. The role of the teachers inside the classroom is authoritative with the least participation of students (Behlol, 2009).

Some research indicates that English students need to learn the academic content while simultaneously they develop their English language skills (Cadeiro \& Rodriguez, 2008). They need to learn new information and procedures while they learn new vocabularies, structures, and academic discourses (McKeown et al., 2004).

In Indonesia, many English teachers to whom the researcher has spoken stated that they have not received any special training on how to teach students effectively. As a result, they frequently feel frustrated with the responsibility. They believe that they are not adequately prepared to meet their students' needs in academically demanding subjects such as science and issues related to disaster (Gandara \& Driscoll, 2005; Wei et al., 2009).

Mean scores, the role of language is important because it is used to communicate inquiries, procedures, and understanding to other people so that they can make informed decisions and take informed actions (Yore \& Hand, 2003). Therefore, learning English will be meaningful since its learning involves learning convention of literacy, such as vocabulary, syntax, spelling, and punctuation in social and academic contexts (Stoddart et al., 2002). Nevertheless, most English teachers assume that ESL students must acquire English before learning subject matters (August \& Hakuta, 1997). 
This is in accordance with the dominant instructional approach, which sees the teaching of English language as separate from the teaching of academic contents because it is assumed that proficiency in English is a prerequisite for learning subject matters (Cummins, 2000).

Research indicates that the content of the inclusive classroom should be driven by an integration of both disciplinary knowledge and language acquisition (de Jong \& Harper, 2008).This means that mainstream teachers need knowledge of second language acquisition and an understanding of the differences between the communicative and academic English (Karabenick \& Noda, 2004). Considering the importance of mastering English for children to face the challenges in their future life, the education of scholars and researchers of developed and developing countries has recognized modules as the most beneficial and effective learning resource. It is a specific learning resource because a group of contents or single subject matter content are covered in the module. It ensures active participation of students to make the learning process alive and dynamic (Ali \& Elfessi, 2004).

In line with that, teaching English to students using modules will enable the students to obtain corrections of the learning activities or tasks at the spot. As a result, they are highly motivated in the learning activities given in the modules. As pointed out by Biran (2000), a module is an entirely individualized package that gives students time to think over, reflect and adjust new information with the already existing frame of knowledge. Moreover, Behlol (2009) indicated that the key advantages of introducing modules in language teaching are that they help to improve the fluency of language, allow full room for individual differences, and provide an opportunity to students to travel at their own pace. The advantages used anywhere outside the institution can be administered to single or group users can be easily revised and upgraded, economical to prepare, flexible to use and can be implemented through a variety of scheduling.

Some studies have proved the effectiveness of teaching students using modules. Barnes et al., (2000) who conducted a mini research in five schools and reported their results that modular teaching could increase 
the motivation of the students, especially terrific motivator of lower ability students. In addition to this, the implementation of module tends to be intensive because of time constraints. The increased motivation is related to the setting of short-term objectives and the intensity of teaching approach. Modules are also related to the development of the continuous assessment. The modular teaching does not have the terminal examination and this could be a motivating factor as well as being the fairer method of assessment. Moreover, Brown and Lewis (1997) conducted a study on the importance of module and pointed out that modules are not only used in educational institutions, but it is also used outside the classroom. They were very flexible and could be implemented through a variety of patterns for individual or group users.

Considering the importance of modular teaching for English class, the researcher attempted to explore the effectiveness of English teaching module at middle schools in West Aceh in this paper, while for Ho hypothesis, the researcher assumed that there is no significant difference between the mean scores of the experimental and control group students.

\section{B. Method}

This research applied mixed method (quantitative and qualitative) that involved 30 students A and B of the 8th class from SMPN 1 Meulaboh as well the teachers who taught English at the school. The entry qualifications, age, curriculum including the audio-visual aid facilities were similar. The teachers teaching at middle school level had unified educational standards for the appointments, working hours and mode of operation in the classroom (Diknas, 2010). The sample students of the into two groups: experimental and control groups.

\section{Research Finding}

The statistical tools, such as $t$ test, mean, and the difference of means, standard deviation, and the degree of freedom were applied to analyze the data of the study. 
Ho : There is no significant difference between the mean scores of the experimental and control group

Table 1.1: Group statistics of experimental and control groups

\begin{tabular}{llccc}
\hline Model1 & $\mathrm{N}$ & Mean & Std. Deviation & Std. Error Mean \\
\hline Experimental & 10 & 77.00 & 9.545 & 3.018 \\
Control & 23 & 49.17 & 4.207 & 0.877 \\
\hline
\end{tabular}

This table indicated the analysis of the means, standard deviations, and standard errors of the means of scores of experimental and control group. The mean of score the experimental group was 77.00 and of the control group was 49.17. The standard deviations were 9.545 and 4.207 respectively, while the standard errors of the means were 3.018 and 0.877 respectively. This analysis shows that the scores of both of the groups have a difference, and its significance was calculated by applying $t$ test.

Table 1.2: Significance of difference between the mean scores of the experimental and Control Group

\begin{tabular}{llllllll}
\hline $\begin{array}{c}\text { Type of } \\
\text { Test/group }\end{array}$ & \multicolumn{2}{c}{ Levene's test } & & \multicolumn{2}{c}{ t test } \\
\hline Post test & F & Sig. & T & Df & p value & $\begin{array}{l}\text { Mean } \\
\text { Difference SE D }\end{array}$ \\
\hline Ex+Con & 10.46 & 0.003 & 11.76 & 31 & 0.000 & 27.8 & 2.36 \\
\hline
\end{tabular}

This table shows the difference between the mean scores of the experimental and control groups was significant. The degree of freedom was 31 and difference between the mean scores was 27.82, whereas the difference between standard errors of the means was 2.36. The $p$ value on $t$ test was 0.000 on 0.05 levels, which was highly significant. The significance of the Levene's test was 0.003 , indicating the appropriateness of the application of the $t$ test. 


\section{Discussion}

The data has proved that there was a significant difference between the mean scores of the experimental group and control group. Also, it table shows that the performance of the experimental group was significantly different from the performance of the control group. Therefore, the Ho hypothesis stated that there is no significant difference between the mean scores of the experimental and control groups between them.

In this respect, the students in the experimental group proved the readability, difficulty level, and content organization of the designed material as a module up to the required standard for the secondary level students. It also indicated that the developed material as a module was valid by the higher performance of the students in the experimental group.

Studies conducted by Shipley et al., (2000) and Ali and Elfessi, (2004) proved that module based learning materials had equal benefits for students. It involves the students in the learning process and brings learning to their level. It gives freedom to students to proceed at their own pace; therefore, all students have equal chance to be benefited according to their own capacities. Also, Behlol (2009) did his research on module development at the secondary level in Pakistan and found that the material designed as a module promoted independent learning habits in the learner, provided the opportunity to proceed at his own pace, ensuring active participation. It was also useful for slow as well as of bright students, and enabled the students to comprehend difficult concepts, and kept them on the track.

\section{E. Conclusion}

Modular teaching is a new teaching strategy for arranging learning experiences in education and it has been receiving much attention. The strategy of learning module has become a part of all level of teaching. It can be used in any setting convenient to the student and may be completed at the learner's own pace. Sufficient theories and practices are available for the practical application of modular teaching in the classroom. The results of the study indicated that teaching module in ESL 
class increased students' performance in learning -teaching program. Thus, English teachers may consider using a module and come up with the current issues faced by the students. Teaching module in ESL class increased students' performance in learning -teaching program. The result of this study also stressed the importance of English teacher to be familiar with the module in order to support the performance of students. With the aid of a module, English teaching can be delivered in a more motivating and students centered way at the middle school level.

\section{Bibliography}

Ali, A., \& Elfessi, A. (2004). Examining student's performance and attitudes toward the use of information technology in a virtual and conventional setting. Journal of Interactive Online Learning, 2,3-10.

August, D. \& Hakuta, K. (Eds.) (1997). Improving schooling for languageminority children: A Research Agenda. Washington, DC: National Academy Press.

Barnes, J.P, Mayer, R. Alfred., \& Hayman. (2000). Modularization of Curriculum at Secondary Level. London: Kogan Page.

Behlol, G. (2009). Difficulties of English Teachers in Teaching English to Secondary Classes. (Unpublished, M.ED Research Thesis, Arid Agriculture). University Rawalpindi, Pakistan.

Brown, H.D. (2000). Principles of language learning and teaching (4th ed.). Englewood Cliffs NJ: Prentice-Hall.

Cadiero, Kaplan, K., \& Rodriguez, J. L. (2008). The preparation of highly qualified teachers for English Language Learners: Educational responsiveness for unmet needs. Equity and Excellence in Education, $41,372-387$.

Cummins, J. (2000). The role of Primary Language Development in Promoting Educational Success for Language Minority Students. Los Angeles: California State University.

de Jong, E.J., \& Harper, C.A. (2008). ESL is Good Teaching "plus": Preparing Standard Curriculum Teachers for All Learners. New York: Lawrence Erlbaum Associates. 
Diknas (2010). Undang-Undang Republik Indonesia No 20 tahun 2003 Tentang Sistem Pendidikan Nasional. Jakarta: Biro Hukum dan Organisasi, Sekjen Depdiknas.

Gandara, Maxwell, \& Driscoll, (2005). English Learners in California Schools: Unequal Resources, Unequal Outcomes. Educational Policy Analysis Archive, 11,36-43.

Karabenick, S., \& Noda, P. (2004). Professional Development Implications of Teachers" Beliefs and Attitudes Towards English language learners. Bilingual Research Journal, 8,55-75.

McKeown, R., Hopkins, C. A., Rizzi, R., \& Chrystalbridge, M. (2002, August 20). Education for Sustainable Development Toolkit. Retrieved November 21, 2013, from http://www.esdtoolkit.org/esd_toolkit_v2.pdf

Minkova, D. \& Stockwell, R. (2001). English Words: History and Structure. Cambridge: University Press.

Rajab, T. (2015). An Applied Model of Teaching Materials to Improve Students' Speaking Skill. Jurnal Ilmiah Peuradeun, 3(1), 103-118.

Shipley, C.M., M.M. Cann., \& Hildebrand, J.F.T. (2000). The Psychology of Educational Technology and Instructional Media. London: New Fetter Lane.

Stoddart, T., Pinal, A., Latzke, M. \& Canaday, D. (2002). Integrating inquiry science and language development for English language learners. Journal of Research in Science Teaching, 39, 664-687.

Usman, M. (2015). Teaching Model of Learning English Writing at University. Jurnal Ilmiah Peuradeun, 3(3), 441-450.

Wei, R. C., Darling-Hammond, L., Andree, A., Richardson, N., \& Orphanos, S. (2009). Professional Learning in the Learning Profession: a Status Report on Teacher Development in the United States and Abroad. Dallas, TX: National Staff Development Council.

Yore, L. D. \& Hand, B. M. (2003). Examining the Literacy Component of Science Literacy: 25 Years of Language Arts and Science Research. International Journal of Science Education, 25, 689-725. 